\title{
PENGARUH OZONISASI TERHADAP DO, BOD DAN PERTUMBUHAN BAKTERI DI DALAM LIMBAH CAIR INDUSTRI PENYAMAKAN KULIT
}

\author{
M. Yazid, Aris Bastianudin, Widdi Usada \\ Pusat Teknologi Akselerator dan Proses Bahan, Badan Tenaga Nuklir Nasional
}

\begin{abstract}
ABSTRAK
PENGARUH OZONISASI TERHADAP DO, BOD DAN PERTUMBUHAN BAKTERI DI DALAM LIMBAH CAIR INDUSTRI PENYAMAKAN KULIT. Telah dilakukan penelitian pengaruh ozonisasi terhadap desolved oxygen (DO), biological oxygen demand (BOD) dan pertumbuhan bakteri di dalam limbah cair industri penyamakan kulit. Penelitian ini bertujuan untuk mempelajari pengaruh ozonisasai terhadap proses dekomposisi senyawa organik di dalam limbah ini, dengan indikator penurunan BOD, kenaikan DO dan pertumbuhan bakteri dekomposer. Ozonisasi dilakukan dengan variasi waktu 0, 15, 30, 45, 60, 75, 90, 105, 120, 135, 150, 165, 180, 195 dan 210 menit. Masing-masing sampel limbah yang telah diozonisasi disimpan dalam tabung reaksi steril untuk isolasi bakteri dan sebagian lagi disimpan di dalam botol lain untuk dilakukan pengukuran BOD dan DO. Hasil penelitian ini menunjukkan bahwa

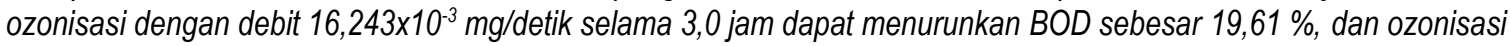
selama 3,5 jam mampu meningkatkan DO sebesar 82,5\%. Selain itu, dengan ozonisasi selama 3,0 jam juga mampu mengurangi pertumbuhan jenis bakteri sebesar $80 \%$.
\end{abstract}

\section{ABSTRACT}

THE INFLUENCE OF OZONISATION FOR DO, BOD AND BACTERIAL GROWTH IN THE LIQUID WASTE FROM TANNING LEATHER INDUSTRY. The research of ozonisation influence of desolved oxygen (DO), biological oxygen demand $(B O D)$ and the bacterial growth in the liquid waste from tanning leather industry has been done. The objetives of this research was to studied the influence of ozonisation for decomposition process of the organic compound in these waste by indicator of $B O D$ decreased, increated of $D O$ and decomposer bacterial growth. The ozonisation was carried out by time variation 0, 15, 30, 45, 60, 75, 90, 105, 120, 135, 150, 165, 180, 195 and 210 minutes. Each samples of the waste has been ozonited keep in the sterilited reaction tube for isolated of bacterial and the other keep in the botle for $B O D$ and $D O$ measurement. These research results show that ozonisation with $16.243 \times 10^{-4} \mathrm{mg} / \mathrm{detik}$ debit for 3 hours can decreased of BOD were $19.61 \%$, and ozonisation for 3.5 hours can increased of DO were $82.5 \%$. The other hand, 3 hours ozonisation can decreased of kind of bacterial growth were $80 \%$.

\section{PENDAHULUAN}

D alam pengelolaan dan perlindungan lingkungan diperlukan upaya yang terintegrasi dari berbagai aspek, diantara perencanaan, kebijakan, hukum, ekonomi, tata ruang dan demografi serta keteknikan yang mempunyai peran penting dalam pengelolaan lingkungan, khususnya untuk memberikan solusi penyimpangan kualitas kehidupan dan kondisi lingkungan dari keadaan homeostatis ${ }^{(1)}$

Teknologi ozonisasi merupakan salah satu alternatif dalam teknologi pengolahan limbah. Ozon dapat dimanfaatkan untuk membunuh bakteri (sterilization), menghilangkan warna (decoloration), menghilangkan bau (deodoration) dan menguraikan senyawa organik (degradation). Selama itu ozonisasi dianggap mampu menyelesaikan persoalan pencemaran limbah cair industri, terutama karena limbah cair yang terozonisasi tidak lagi keruh dan berbau. Yang menjadi permasalahan adalah apakah ozonisasi mampu menyelesaikan pencemaran logam berat yang terkandung dalam limbah cair industri, mengingat bahwa dalam setiap limbah cair industri tidak hanya terdapat limbah organik melainkan juga limbah anorganik, termasuk pencemar logam berat. Dalam limbah cair yang mengandung logam berat, pasti terdapat kelompok mikroorganisme yang mempunyai sifat toleran dan resisten yang tinggi terhadap kandungan logam berat tersebut. Hal inilah yang menjadikan penerapan ozonisasi dirasa masih memerlukan pengolahan lanjutan (advance treatment). ${ }^{(1,2)}$

Peran ozonisasi sebagai agen sterilisasi mampu menyeleksi kelompok bakteri resisten ozon karena ozonisasi limbah cair dengan waktu ozonisasi tertentu dipandang masih mengandung beberapa koloni bakteri. Penelitian ini bertujuan untuk mempelajari pengaruh ozonisasi terhadap kualitas limbah industri, khususnya BOD, DO dan pertumbuhan bakteri. Perlakuan ini dimaksudkan untuk melakukan seleksi genus bakteri sehingga akan 
mengurangi kompetisi antar genus bakteri itu sendiri, yang diharapkan proses degradasi senyawa organik di dalam limbah tersebut akan berjalan lebih efektif yang diindikasikan dengan penurunan BOD dan kenaikan DO.

\section{TATA KERJA}

\section{Bahan yang digunakan}

Limbah cair pabrik penyamakan kulit pada bak equalisasi, Media Brain Heart Infusion (BHI), Media Tryptone Bile X-Clucuronide (TBX), Media Endo Agar Base (EA), Media Mac Concey Agar (MC), Media Blood Agar Plate (BP), Media Cetrimide Agar (CTM), aquades steril, kapas steril, kassa steril, alkohol $70 \%$

\section{Alat yang digunakan}

Ozonizer dengan kapasitas $1.6243 \times 10^{-3} \mathrm{mg} /$ detik, Incubator shaker merek "Eyela", Autoklaf "All American", Inkubator "Kelvitron", Colony counter, pH meter, mikroskop binokuler, cawan petri, jarum ose, mikro pipet, peralatan gelas laboratorium

\section{Cara kerja}

\section{Pengambilan Sampel}

Pengambilan sampel limbah cair dilakukan pada bak equalisasi dari instalasi pengolahan air limbah (IPAL) pabrik kulit secara aseptis mengunakan botol steril sebanyak 3 I. Sampel limbah diambil dengan mengalirkan air limbah dari pipa penyalur secara langsung ke dalam botol. Selama proses, disediakan api bunsen untuk menghindari kontaminasi mikroorganisme di udara sekitarnya.

2. Penentuan sifat fisikawi dan kimiawi limbah

Sifat fisikawi limbah yang ditentukan adalah bau dan suhu, sedangkan sifat kimiawi adalah BOD, DO, dan $\mathrm{pH}$ sampel. Nilai $\mathrm{pH}$ diukur dengan $\mathrm{pH}$ meter. Penentuan nilai $\mathrm{DO}$ dengan menggunakan alat $\mathrm{DO}$ meter. Nilai $\mathrm{BOD}, \mathrm{DO}$ dan $\mathrm{pH}$ ditentukan sebelum dan sesudah perlakuan.

3. Pemberian perlakuan ozonisasi

Sampel limbah dalam botol steril dikontakkan dengan pipa keluaran gas ozon pada tabung ozonizer. Proses ozonisasi dilakukan dengan variasi waktu $0,15,30,45,60,75,90,105,120,135,150,165,180$, 195 dan 210 menit. Pemilihan variasi waktu ozonisasi berdasarkan variasi yang dilakukan pada uji pendahuluan. Masingmasing sampel limbah yang telah diozonisasi disimpan dalam tabung reaksi steril untuk isolasi bakteri. Sebagian disimpan dalam botol steril untuk pengujian BOD dan DO.

4. Penentuan kurva pertumbuhan isolat terseleksi

Kurva pertumbuhan ditentukan dengan mengukur pertumbuhan bakteri dalam interval waktu yang konsisten. Dari kurva tersebut akan terlihat fase eksponensial yang merupakan fase pertumbuhan aktif bakteri. Penentuan fase ini sangat penting karena pada fase itu bakteri akan menghasilkan banyak enzim untuk pertumbuhan dan pembelahan sel. Dengan demikian diharapkan terjadi degradasi senyawa organik yang efektif pada fase eksponensial ini.

Penentuan kurva pertumbuhan dilakukan dengan menginokulasikan kultur bakteri terseleksi ke dalam media $\mathrm{BHI}$. Inokulum tersebut diinkubasikan pada suhu $37^{\circ} \mathrm{C}$ dan dilakukan pengukuran secara spektrofotometri pada panjang gelombang $620 \mathrm{~nm}$ pada jam ke 0 sampai dengan 48. Fase eksponensial isolat bakteri terseleksi dapat diketahui dari grafik hubungan antara waktu inkubasi dengan absorbansi inokulum. ${ }^{(3)}$

\section{HASIL DAN PEMBAHASAN}

\section{Penentuan sifat fisikawi dan kimiawi limbah.}

Penentuan sifat fisika dan kimia limbah ditentukan dari kadar $\mathrm{Cr}, \mathrm{pH}, \mathrm{BOD}$ dan $\mathrm{DO}$ limbah cair pada bak equalisasi dan bak aerasi akhir. Penentuan parameter tersebut digunakan untuk mengetahui kondisi awal limbah. Hasil pengukurannya adalah sebagai berikut : 
Tabel 1. Hasil Karakterisasi Limbah Cair Proses Penyamakan Kulit

\begin{tabular}{|l|l|c|c|c|}
\hline No & Tempat pengambilan Limbah & $\mathrm{pH}$ & $\mathrm{BOD}(\mathrm{mg} / \mathrm{l})$ & $\mathrm{DO}(\mathrm{mg} / \mathrm{l})$ \\
\hline 1. & Bak Equalisasi & 9,0 & 7508,6 & 0,2 \\
\hline 2. & Bak Aerasi Akhir & 7,0 & 5427,1 & 3,4 \\
\hline
\end{tabular}

Pada Tabel 1. dapat diketahui bahwa limbah cair proses penyamakan kulit pada bak equalisasi dan bak aerasi akhir, BOD masih berada di atas ambang batas yang ditentukan berdasarkan KEP 51/MENLH/10/1995. yaitu $<50 \mathrm{mg} / \mathrm{l}$. Dengan demikian masih diperlukan treatment lanjutan, sehingga kualitas limbah dapat memenuhi ketentuan yang berlaku.

\section{Pengaruh Ozonisasi terhadap parameter fisikawi dan kimiawi limbah}

Sampel limbah cair proses penyamakan kulit diambil dari bak equalisasi selanjutnya dilakukan ozonisasi hingga 210 menit dalam interval waktu 15 menit. Sampel yang telah diozonisasi dianalisis sifat fisika dan kimianya. Hasil analisis disajikan pada tabel berikut:

Tabel 2. Pengaruh ozonisasi terhadap kualitas limbah cair

\begin{tabular}{|c|c|c|c|c|c|c|c|c|c|c|c|}
\hline \multirow{2}{*}{ No } & \multirow{2}{*}{\begin{tabular}{|c|} 
Waktu \\
Ozonisasi \\
(Menit)
\end{tabular}} & \multicolumn{2}{|c|}{$\begin{array}{c}\text { PARAMETER } \\
\text { FISIKAWI }\end{array}$} & \multicolumn{3}{|c|}{ PARAMETER KIMIAWI } & \multicolumn{5}{|c|}{ PERTUMBUHAN BAKTERI } \\
\hline & & Bau & Suhu & $\mathrm{BOD}(\mathrm{mg} / \mathrm{l})$ & $\mathrm{pH}$ & $\mathrm{DO}(\mathrm{mg} / \mathrm{l})$ & BCR1 & $\mathrm{BCR} 2$ & BCR3 & BCR4 & BCR5 \\
\hline 1 & 0 & + & 29,5 & 5032,6 & 9,5 & 0,4 & + & + & + & + & + \\
\hline 2 & 15 & + & 29,7 & 4440,6 & 9,5 & 0,6 & - & + & - & + & + \\
\hline 3 & 30 & + & 29,4 & 4637,1 & 9,5 & 0,8 & + & + & + & + & - \\
\hline 4 & 45 & + & 29,4 & 4440,6 & 9,0 & 0,6 & + & + & + & - & - \\
\hline 5 & 60 & + & 29,4 & 4440,6 & 9,5 & 0,9 & - & + & + & - & - \\
\hline 6 & 75 & + & 29,5 & 4539,1 & 9,5 & 0,9 & - & + & + & - & - \\
\hline 7 & 90 & + & 29,5 & 4341,1 & 9,0 & 1,3 & - & + & - & - & - \\
\hline 8 & 105 & - & 29,5 & 4144,6 & 9,0 & 1,6 & - & + & + & - & - \\
\hline 9 & 120 & - & 29,6 & 4637,1 & 9,0 & 2,2 & - & + & - & - & - \\
\hline 10 & 135 & - & 29,6 & 4243,1 & 9,5 & 2,4 & - & + & - & - & - \\
\hline 11 & 150 & - & 29,7 & 4243,1 & 9,5 & 2,8 & - & + & - & - & - \\
\hline 12 & 165 & - & 29,5 & 4637,1 & 9,0 & 2,8 & - & + & - & - & - \\
\hline 13 & 180 & - & 29,6 & 4045,6 & 9,0 & 2,9 & - & + & - & - & - \\
\hline 14 & 195 & - & 29,6 & 4045,6 & 9,0 & 3,2 & - & - & - & - & - \\
\hline 15 & 210 & - & 29,5 & 4045,7 & 9,0 & 3,3 & - & - & - & - & - \\
\hline
\end{tabular}

Keterangan :

Debit Ozonizer : 16,243×10-4 mg/detik, + : Bau Limbah Sangat Menonjol, - : Bau Limbah Berkurang dan Bau Ozon Menonjol

Tempat pengambilan sampel dilakukan pada bak equalisasi karena merupakan limbah cair gabungan dari limbah organik dan anorganik, yang memiliki pH 9.0 hingga 9.5. Hal ini sesuai dengan sifat kimiawi ozon yang efektif bekerja dalam suasana basa $(\mathrm{pH}>7)^{(2,4)}$. Di samping itu limbah cair pada bak equalisasi merupakan limbah awal sebelum masuk ke tahap pengolahan air limbah sehingga diharapkan perlakuan ozonisasi merupakan metode alternatif untuk pengolahan air limbah. Ozonisasi dilakukan pada variasi waktu $0,15,30,45,60,75,90$, 105, 120, 135, 150, 165, 180, 195 dan 210 menit. Pemilihan variasi waktu ozonisasi berdasarkan variasi waktu ozonisasi pada uji pendahuluan yaitu 30,60, 90 dan 120 menit. Pada sampel limbah dengan waktu ozonisasi 120 menit, masih terdapat isolat yang resisten ozon sehingga diperlukan variasi waktu ozonisasi yang lebih rapat dan lama dari variasi waktu uji pendahuluan. Hal ini dimaksudkan untuk mengetahui berapa lama proses ozonisasi mampu mematikan seluruh bakteri dalam limbah.

Sifat fisikawi dan kimiawi limbah yang diukur adalah bau, suhu, pH, BOD dan DO sebelum dan sesudah perlakuan. Hal ini untuk mengetahui pengaruh ozon terhadap sifat fisika dan kimia limbah. Fungsi ozon sebagai 
deodorant ditunjukkan pada pengurangan bau limbah setelah ozonisasi. Dari Tabel 2 dapat diketahui bahwa bau limbah masih sangat dominan hingga ozonisasi 120 menit. Bau berkurang dan digantikan oleh bau ozon seperti klorin mulai pada menit ke 135. Hal ini mungkin disebabkan BOD pada limbah masih tinggi. Disamping itu, kandungan bahan organik pada limbah memang tergolong tinggi, menilik dari asal pengaliran limbah.

Suhu limbah pada berbagai variasi perlakuan tidak mengalami perubahan, yaitu hanya berkisar pada $\pm 29^{\circ} \mathrm{C}$. Demikian pula nilai $\mathrm{pH}$ yang berkisar pada $\mathrm{pH}$ 9. Hal ini disebabkan ozon memang relatif tidak berpengaruh pada suhu dan $\mathrm{pH}^{(7)}$

Pengaruh ozonisasi terhadap nilai BOD dan DO air limbah ditunjukkan pada gambar berikut :

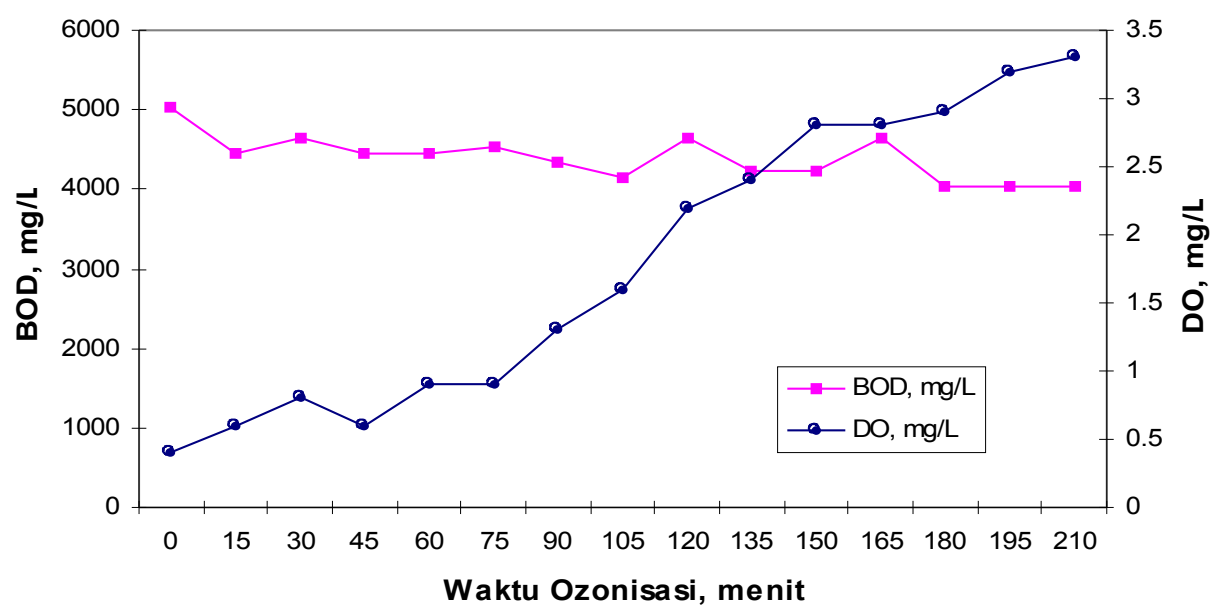

Gambar 1. Pengaruh ozonisasi terhadap nilai BOD dan DO dalam air limbah

Gambar 1. menunjukkan bahwa pada ozonisasi selama 15 menit dapat menurunkan BOD dari $5032.6 \mathrm{mg} / \mathrm{l}$ menjadi 4440,6 mg/l. Hal ini disebabkan ada beberapa bakteri yang lemah karena ozon yaitu BCR3 dan BCR1 sehingga mengurangi pemakaian oksigen untuk mendegradasi bahan organik limbah. Namun pada ozonisasi 30 menit, terjadi peningkatan BOD limbah menjadi $4637,1 \mathrm{mg} / \mathrm{l}$. Hal ini menunjukkan terdapat bakteri yang mulai resisten terhadap ozon, sehingga pemakaian oksigen untuk mendegradasi bahan organik limbah kembali meningkat. Mulai menit ke 45, BOD kembali mengalami penurunan hingga menit ke 210. Hal ini karena hingga waktu ozonisasi 180 menit, hanya BCR2 saja yang resisten ozon dan melakukan pemakaian oksigen dalam limbah sehingga ozonisasi berlangsung optimal hingga 210 menit. Ozonisasi sebesar $16,243 \times 10^{-4} \mathrm{mg} / \mathrm{detik}$ mampu menurunkan BOD sebesar 19,61 \%, yaitu dari 5032,6 menjadi 4045,6 mg/l selama 180 menit atau 3 jam. Jika dibandingkan dengan pengolahan IPAL pabrik penyamakan kulit, ozonisasi ini lebih cepat menurunkan BOD limbah cair. Pada Tabel 1. Hasil Karakterisasi Limbah Cair Proses Penyamakan Kulit. BOD limbah pada bak aerasi akhir yaitu limbah sesudah mengalami pengolahan IPAL tahap akhir sebesar 5427,1 mg/l. Sedangkan BOD limbah awal sebelum pengolahan IPAL sebesar 7508,6 mg/l. Penurunan BOD ini adalah 27,72\%. Namun berlangsung dalam waktu 48 jam sehingga jauh lebih lama. Sedangkan kadar DO dalam limbah cair setelah perlakuan cenderung mengalami peningkatan hingga waktu ozonisasi 210 menit. Peningkatan nilai DO menunjukkan bahwa konsentrasi oksigen terlarut dalam limbah mulai meningkat setelah perlakuan ozonisasi. Hal ini mungkin disebabkan faktor dekomposisi ozon dan bakteri yang terseleksi oleh ozonisasi. Prinsip produk dekomposisi ozon dalam larutan adalah molekul $\mathrm{O}_{2}$ dan radikal-radikal bebas yang sangat reaktif, yaitu $\mathrm{HO}^{2-}, \mathrm{OH}^{-}$dan $\mathrm{H}^{+(6)}$. Sifat reaktif tersebut menunjukkan bahwa radikal bebas mudah berikatan dengan senyawa organik bakteri sehingga merusak dan mematikan bakteri dalam limbah. Dalam penelitian ini dosis ozon yang dihasilkan dari ozonizer mampu mematikan bakteri dan hanya isolat tertentu saja yang resisten. Diantara isolat bakteri yang ada, hanya BCR2 saja yang resisten ozon sehingga kadar oksigen dalam limbah yang dikonsumsi BCR2 tidak terlampau besar. Jika oksigen yang dikonsumsi kecil maka kadar oksigen yang terlarut atau tersedia dalam limbah menjadi besar sehingga nilai DO cenderung naik. Di samping itu peningkatan nilai DO dalam limbah disebabkan adanya molekul $\mathrm{O}_{2}$ yang merupakan hasil samping dari dekomposisi ozon sehingga menambah kandungan oksigen dalam 
limbah. Dengan demikian perlakuan ozonisasi sebesar $16,243 \times 10^{-4} \mathrm{mg} /$ detik mampu menaikkan DO sebesar $825 \%$ yaitu dari 0,4 menjadi $3,3 \mathrm{mg} / \mathrm{l}$ selama 210 menit atau $3,5 \mathrm{jam}$.

\section{Pengaruh Ozonisasi terhadap pertumbuhan bakteri}

Pengaruh ozonisasi terhadap pertumbuhan isolat bakteri disajikan pada Tabel 3 berikut :

Tabel 3. Pengaruh ozonisasi terhadap pertumbuhan isolat

\begin{tabular}{|l|l|c|c|c|c|c|}
\hline No & $\begin{array}{l}\text { Waktu Ozonisasi } \\
\text { (Menit) }\end{array}$ & BCR1 & BCR2 & BCR3 & BCR4 & BCR5 \\
\hline 1. & 0 & + & + & + & + & + \\
\hline 2. & 15 & - & + & - & + & + \\
\hline 3. & 30 & + & + & + & + & - \\
\hline 4. & 45 & + & + & + & - & - \\
\hline 5. & 60 & - & + & + & - & - \\
\hline 6. & 75 & - & + & + & - & - \\
\hline 7. & 90 & - & + & - & - & - \\
\hline 8. & 105 & - & + & + & - & - \\
\hline 9. & 120 & - & + & - & - & - \\
\hline 10. & 135 & - & + & - & - & - \\
\hline 11. & 150 & - & + & - & - & - \\
\hline 12. & 165 & - & + & - & - & - \\
\hline 13. & 180 & - & + & - & - & - \\
\hline 14. & 195 & - & - & - & - & - \\
\hline 15. & 210 & - & - & - & - & - \\
\hline
\end{tabular}

Keterangan :

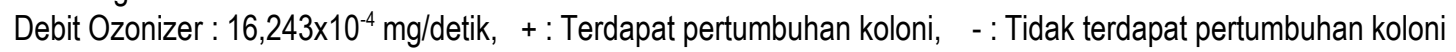

Tabel 3 menunjukkan bahwa isolat bakteri BCR1, BCR4 dan BCR5 tidak dapat tumbuh setelah diberikan perlakuan ozonisasi selama 60 menit. BCR3 masih terdapat pertumbuhan koloni dan pada saat ozonisasi 120 menit mulai tidak terjadi pertumbuhan. Sedangkan BCR2 masih terjadi pertumbuhan sampai ozonisasi 180 menit. Dengan demikian dapat dikatakan bahwa isolat BCR2 merupakan isolat yang telah terseleksi dalam proses ozonisasi.

\section{Identifikasi isolat bakteri terseleksi}

Identifikasi isolat bakteri yang terseleksi dengan proses ozonisasi (BCR2) dilakukan dengan metode kesamaan profil (matching profile) berdasarkan genus acuan yang ditelusuri melalui Bergey's Manual of Determinative Bacteriology. Hasil identifikasi bakteri disajikan pada tabel berikut :

Tabel 4. Hasil identifikasi BCR2

\begin{tabular}{|c|c|c|c|}
\hline \multirow{2}{*}{ No } & \multirow{2}{*}{ KARAKTERISASI } & \multicolumn{2}{|c|}{ HASIL IDENTIFIKASI } \\
\hline & & GENUS BACILLUS & BCR2 \\
\hline 1. & Bentuk & Batang berspora & Batang berspora \\
\hline 2. & Susunan sel & Tunggal atau berpasangan & Tunggal atau berpasangan \\
\hline 3. & Reaksi gram & Positif & Positif \\
\hline 4. & Katalase & + & + \\
\hline 5. & Spora & Tidak ada & Tidak ada \\
\hline 6. & Produksi indol & - & - \\
\hline 7. & Reduksi nitrat & + & + \\
\hline
\end{tabular}

BCR2 juga mampu tumbuh pada media BP agar, yang merupakan media diferensial untuk bakteri Bacillus dan Streptococcus. Berdasarkan hasil identifikasi pada tabel 4, BCR2 diduga merupakan genus Bacillus. 


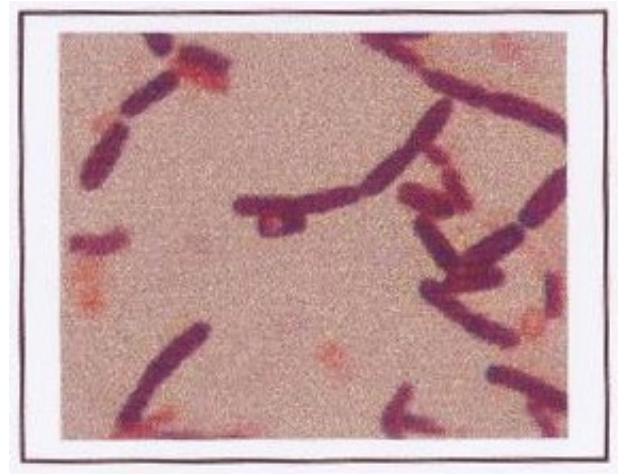

Gambar 2. Bentuk sel BCR2, batang berspora, gram (+)

\section{Penentuan kurva pertumbuhan isolat bakteri terseleksi}

Penentuan kurva pertumbuhan hanya dilakukan pada isolat BCR2 sebagai isolat bakteri yang terseleksi, karena isolat ini yang akan diaplikasikan dalam pengolahan limbah khususnya untuk mendegradasi senyawa organik. Hasil pengukuran OD. (absorbansi) inokulum selama 48 jam dalam interval waktu 2 jam membentuk kurva pertumbuhan yang disajikan pada Gambar 3.

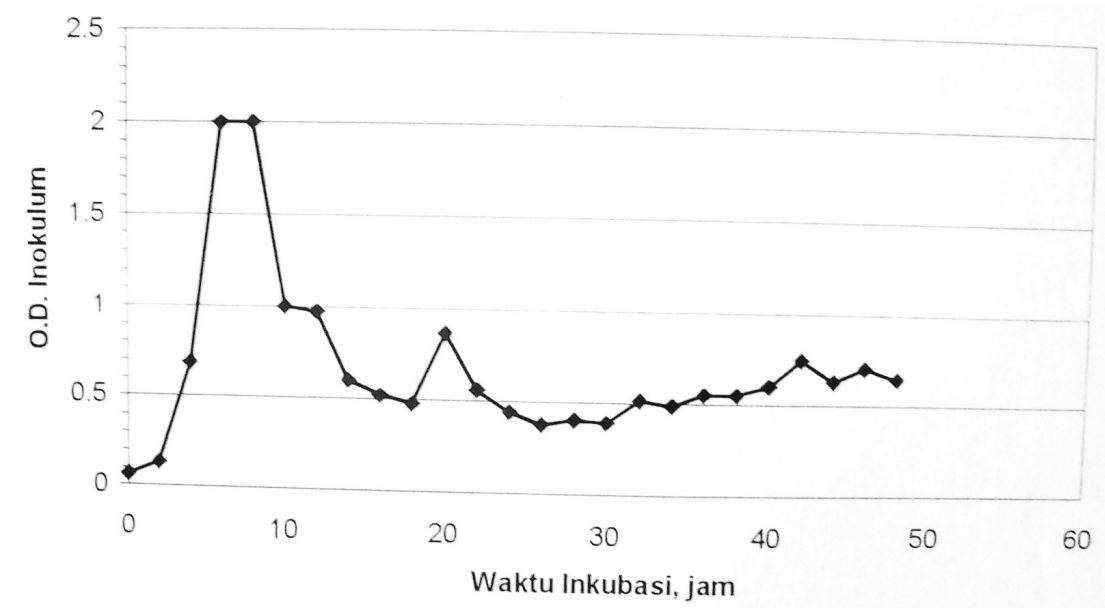

Gambar 3. Kurva Pertumbuhan BCR2

Dari Gambar 3 dapat diketahui bahwa fase eksponensial BCR2 terjadi pada jam kedua sampai dengan jam kedelapan yang ditandai dengan kenaikan OD inokulum. Hal ini menunjukkan bahwa pada jam kedua sampai dengan kedelapan terjadi pertumbuhan aktif bakteri dengan memproduksi berbagai macam enzim yang berguna untuk degradasi senyawa organik secara enzimatik. Dengan demikian diharapkan selama pertumbuhan sel meningkat akan terjadi pula proses degradasi senyawa organik secara efektif. Data inilah yang meruapakan variasi waktu inkubasi yang digunakan pada tahap aplikasi selanjutnya adalah pada jam kedua sampai dengan kedelapan dengan interval waktu 2 jam.

\section{KESIMPULAN}

1. Ozonisasi dengan kapasitas $16,243 \times 10^{-4} \mathrm{mg} /$ detik selama 3,0 jam, dapat menurunkan BOD sebesar sebesar $19,61 \%$, yaitu dari 5032,6 menjadi 4045,6 mg/l dan ozonisasi selama 3,5 jam dapat meningkatkan DO sebesar $82,5 \%$, yaitu dari $0.4 \mathrm{mg} / \mathrm{l}$ menjadi $3,3 \mathrm{mg} / \mathrm{l}$

2. Proses ozonisasi selama 3,0 jam juga mampu menseleksi pertumbuhan genus bakteri sebesar $80 \%$, yaitu dari 5 genus menjadi tinggal satu genus saja. Fase eksponensial dari bakteri terseleksi (BCR2) terjadi pada jam kedua sampai dengan kedelapan dengan interval waktu 2 jam. 


\section{DAFTAR PUSTAKA}

1. NORMA AFIATI., "Toksikologi Lingkungan: Sampling dan Preparasi Sampel Lingkungan Untuk Analisis Sampel Kelumit" Pusdiklat BATAN Jakarta, (2007)

2. ISYUNIARTO dkk., "Degradasi Fenol dalam Limbah Pengolah Minyak Bumi Dengan Ozon". Prosiding Pertemuan dan Presentasi IImiah Penelitian Dasar IImu Pengetahuan dan Teknologi Nuklir. ISSN 0216-3128. 12 Juli 2005. PTAPB BATAN Yogyakarta, (2005)

3. BENSON, H.J., Microbiological Applicationns Laboratory Manual in General Microbiology, Seventh Edition. The McGraw-Hill Co Inc. New York, (1998)

4. YEEN WS., "Construction and Studies of a Plasma Ozonizer", Malaya Department of Physics University of Malaya, (1996)

5. USADA W dkk, "Prototipe Sistem Desinfektan Dalam Air Dengan Plasma Ozonizer 100 W", Prosiding Pertemuan dan Presentasi IImiah Penelitian Dasar IImu Pengetahuan dan Teknologi Nuklir ISSN 0216-3128. 13 Juli 2004 PTAPB BATAN Yogyakarta, (2004)

6. MISRA, T.K., Heavy metals, Bacterial resistances, Encyclopedia of Microbiology, Volume 2 D-L USA: American Society For Microbiology, (1992)

7. MCELDOWNEY, S., DAVID, J.H., \& STEPHEN, W., Pollution: Ecology and Biotreatment. First Ed. Longman Scientific Singapore Publisher Ltd. Singapore, (1993).

8. M. YAZID \& ARIS BASTIANUDIN., "Isolasi dan Identifikasi Bakteri Pengikat Stronsium dalam Limbah Radioaktif Cair Aktivitas Rendah", Prosiding Temu IImiah Jaringan Kerjasama Kimia Indonesia, Yayasan Media Kimia Utama, (2006) 